\title{
Management of Early Leaf Spot (Cercospora arachidicola) of Groundnut in Rajasthan
}

\author{
Vikash Kumar, Narendra Singh ${ }^{1}$, B.D.S. Nathawat ${ }^{2}$, Data Ram Kumhar
}

10.18805/LR-4708

\begin{abstract}
Background: Early leaf spot caused by Cercospora arachidicola Hori. is most destructive disease in all the groundnut growing areas of Rajasthan, under severe infestation it cause $30-50 \%$ losses in pod yield. Recently, Central Insecticide Board (CIB), Faridabade banned 27 pesticides including some important fungicides which are extensively used in plant disease management. Therefore, in the present investigation, our main emphasis was to find out some new fungicides for management of early leaf spot disease.

Methods: Ten fungicides (hexaconazole 5\% EC, difenconazole $25 \%$ EC, propiconazole $25 \%$ EC, tebuconazole $25.9 \%$ EC, trifloxystrobin $25 \%$ + tebuconazole $50 \%$ WG, mancozeb $50 \%$ WP, chlorothalonil $75 \%$ WP, carbendazim $50 \%$ WP, carbendazim $12 \%+$ mancozeb $63 \%$ WP and captan $70 \%+$ hexaconazole $5 \%$ WP) were evaluated against early leaf spot pathogen (C. arachidicola) both in lab as well as in field condition. The experiment was conducted at ARS, SKRAU, Bikaner during Kharif-2019 on most popular cv. HNG-69 in RBD design with the application of foliar spray of ten different fungicides at different concentrations against early leaf spot disease and compared with an untreated control.

Result: Among all the fungicides used in the present investigation, Tebuconazole $25.9 \%$ EC was found most effective in inhibiting the mycelial growth of the pathogen followed by trifloxystrobin 25\% + tebuconazole 50\% WG. Under field condition, it gave maximum (70.73\%) disease control with highest pod yield (31.5 q/ha) and net return (Rs 57,500/ha) when applied as foliar spray at $0.1 \%$ concentration followed by trifloxystrobin $25 \%$ + tebuconazole $50 \% \mathrm{WG}$ at $0.2 \%$. These treatments can provide an effective and economical management of early leaf spot disease for groundnut cultivators.
\end{abstract}

Key words: Cercospora arachidicola, Early leaf spot, Fungicides, Groundnut.

\section{INTRODUCTION}

Groundnut (Arachis hypogaea L.) also known as peanut or earthnut which belongs to the sub family Papilionaceae of the family Leguminosae. It is an annual legume native to South America. It is grown in most tropical, sub-tropical and warm temperate regions of the world between $40^{\circ}$ North and $40^{\circ}$ South latitudes (Basu and Singh, 2004). It is an important oilseed and supplementary food crop of the world. It is fourth most important source of edible oil and third most important source of vegetable protein. Groundnut seed contains 9.5 to $19.0 \%$ total carbohydrates (Oke,1967; Savage and Keenan, 1994).

Globally India ranks first in groundnut acreage and second in production. The total area under groundnut cultivation in India was 39.31 lakh hectares with the total production of 68.63 lakh MT and average productivity of $1,745 \mathrm{~kg} \mathrm{ha}^{-1}$ during the year 2018-19. Eighty per cent of the total groundnut area is confined to five states viz., Gujarat Andhra Pradesh, Tamil Nadu, Karnataka and Maharashtra. The rest of the area and production is distributed mainly in the states of Rajasthan, Uttar Pradesh, Madhya Pradesh, Punjab and Orissa. It is cultivated during kharif season (June- July to September- October) mostly under rainfed conditions. few protective irrigations (Anonymous, 2019). Groundnut cultivated area in Rajasthan was 7.34 lakh hactares, with production of $16.12 \mathrm{MT}$ and productivity 1580 $\mathrm{kg} \mathrm{ha}^{-1}$ during the year 2018-19. Groundnut is mainly cultivated in Bikaner, Jodhpur, Churu, Jaislmer, Jaipur, Sikar
Department of Plant Pathology, College of Agriculture, Swami Keshwanand Rajasthan Agricultural University, Bikaner-334 006, Rajasthan, India.

${ }^{1}$ AINP on Arid Legumes, Agricultural Research Station, Swami Keshwanand Rajasthan Agricultural University, Bikaner-334 006, Rajasthan, India.

${ }^{2}$ AICRP on Groundnut, Agricultural Research Station, Swami Keshwanand Rajasthan Agricultural University, Bikaner-334 006, Rajasthan, India.

Corresponding Author: Narendra Singh, AINP on Arid Legumes, Agricultural Research Station, Swami Keshwanand Rajasthan Agricultural University, Bikaner-334 006, Rajasthan, India.

Email: singhnarendra35 @yahoo.com

How to cite this article: Kumar, V., Singh, N., Nathawat, B.D.S. and Kumhar, D.R. (2021). Management of Early Leaf Spot (Cercospora arachidicola) of Groundnut in Rajasthan. Legume Research. DOI: 10.18805/LR-4708.

Submitted: $22-06-2021$

Accepted: $16-10-2021$

Online: $25-11-2021$

and Nagaur districts of Rajasthan. In Bikaner district, the area under groundnut cultivation increasing day by day due to its high selling price. Bikaner district has grown maximum area of groundnut (2.45 lakh ha), with total production 5.29 lakh tonnes and productivity $2159 \mathrm{~kg} \mathrm{ha}^{-1}$ during 2018-19 (Annonymous, 2019).

The crop is suffered from several biotic factors viz., fungal, bacterial and viral diseases that limits its production 
and productivity. However, only a few are economically important in India, such as fungal diseases like early leaf spot (Cercospora arachidicola), late leaf spot (Cercosporidium personatum) and Collar rot/Crown rot (Aspergillus niger and A. pulverulentus). Among the fungal diseases, the early leaf spot caused by Cercospora arachidicola is the major disease at early stage of groundnut crop in Rajasthan. The yield losses due to this disease could be as high as 30-50 per cent (Subrahmanyam et al., 1980, Damicone et al., 1999; Mohammed, 2004). The disease infects crop directly as well as indirectly and results in huge losses due to leaf defoliation, disruption of photosynthesis and fewer pods that are inferior in quality (Waliyar et al., 2000). Losses are even more when crop is unsprayed. Leaf spot alone reduces 43.01 per cent in pod yield, 15.95 per cent in kernel weight and 32.9 per cent in dry matter weight (Ghuge et al., 1981). The disease is endemic in Rajasthan and causes heavy losses in yield of groundnut crop.

The fungicides are the most common tools for controlling disease losses. Recently, Central Insecticide Board (CIB), Faridabade banned 27 pesticides including some important fungicides which are extensively used in plant disease management. These were captan, carbendazim, mancozeb, thiram, zineb, ziram and thiophanate methyl. Therefore, it is an urgent need to find out some new fungicides which are effective against early leaf spot disease. Hence, keeping in view the importance of groundnut crop and potential threat of $C$. arachidicola in all the groundnut growing areas in the Rajasthan, the present investigation was undertaken to manage of this important disease through new fungicides.

\section{MATERIALS AND METHODS}

Efficacy of each fungicides were tested against Cercospora arachidicola both in lab as well as in field condition.

\section{To evaluate the efficacy of fungicides against Cercospora arachidicola in vitro}

The efficacy of fungicides against mycelial growth of $C$. arachidicola was tested at 50,100, 200 and 500 ppm concentrations. Ten fungicides were evaluated in this study. These were $\mathrm{T}_{1}$ : Hexaconazole $5 \% \mathrm{EC}, \mathrm{T}_{2}$ : Difenconazole $25 \%$ EC, $\mathrm{T}_{3}$ : Propiconazole 25\% EC, $\mathrm{T}_{4}$ : Tebuconazole $25.9 \%$ EC, $\mathrm{T}_{5}$ : Trifloxystrobin $25 \%+$ tebuconazole $50 \% \mathrm{WG}$, $\mathrm{T}_{6}$ : Mancozeb 75\% WP , $\mathrm{T}_{7}$ :Chlorothalonil 75\% WP, $\mathrm{T}_{8}$ : Carbendazim 50\% WP, T: Carbendazim 12\% + mancozeb $63 \% \mathrm{WP}$ and $\mathrm{T}_{10}$ : Captan $70 \%$ + hexaconazole 5\% WP (Table-1). The efficacy against mycelial growth was tested using Poisoned-Food-Technique (Nene and Thapliyal, 1973). Required quantities of fungicide was thoroughly mixed in melted PDA, just before pouring in sterilized petri dishes and were allowed to solidify for $12 \mathrm{hrs}$. Each plate was then inoculated with $5 \mathrm{~mm}$ disc of mycelial bit taken from the periphery of 10 days colony of $C$. arachidicola growing on PDA. The inoculated petri dishes were incubated at $25 \pm 1^{\circ} \mathrm{C}$. Three plates were used for each treatment serving as three replications. Colony diameter (two diagonals) was measured after 15 days of incubation. Medium without fungicide served as control. Per cent growth inhibition was calculated by Vincent's (1947) formula as follows:

Where

$$
I=\frac{C-T}{C} \times 100
$$

I = Mycelial growth inhibition (\%).

$\mathrm{C}=$ Diameter of the colony in check (average of both diagonals).

$\mathrm{T}=$ Diameter of the colony in treatment (average of both diagonals).

\section{To manage early leaf spot disease of groundnut through fungicides in vivo}

To find out the efficacy of different fungicides on early leaf spot disease of groundnut, a field experiment was undertaken at Agricultural Research Station, Swami Keshwanand Rajasthan Agricultural University, Bikaner during kharif- 2019. A most popular groundnut cultivar HNG69 was used in this experiment. The groundnut was sown on $16^{\text {th }}$ July 2019 . The crop was planted at $30 \mathrm{~cm}$ row to row and $10 \mathrm{~cm}$ plant to plant spacing. The gross plot size was $3.0 \times 3.0 \mathrm{~m}^{2}$. The experiment was laid out in Randomized Block Design (RBD) with three replications. All other recommended practices required for cultivation of the crop were followed. Ten fungicides were used in this experiment. These were $\mathrm{T}_{1}$ : Hexaconazole $5 \%$ EC $(0.1 \%), \mathrm{T}_{2}$ : Difenconazole $25 \%$ EC $(0.1 \%), \mathrm{T}_{3}$ : Propiconazole $25 \%$ EC $(0.1 \%), \mathrm{T}_{4}$ : Tebuconazole $25.9 \%$ EC $(0.1 \%), \mathrm{T}_{5}$ : Trifloxystrobin 25\% + tebuconazole 50\% WG $(0.2 \%), \mathrm{T}_{6}$ : Mancozeb 75\% WP (0.2\%), T 7 :Chlorothalonil 75\% WP (0.2\%):, T. Carbendazim 50\% WP (0.2\%), T: Carbendazim $12 \%+$ mancozeb 63\% WP $(0.15 \%), \mathrm{T}_{10}$ : Captan $70 \%+$ hexaconazole $5 \%$ WP $(0.2 \%)$ and $\mathrm{T}_{11}$ : control (Table- 2$)$. The first spray of fungicides was applied separately when disease symptoms were initiated on the foliage. Disease intensity was recorded after one month of spraying. For this, ten plants randomly taken from each plots were assessed for per cent leaf area affected with the help of disease assessed key (0-9) developed by Subrahmanyam et al. (1982) as healty- $1 ; 2,>1$ to $5 ; 3,>6$ to $10 ; 4,>11$ to $20 ; 5$, $>21$ to $30 ; 6,>31$ to $40 ; 7,>41$ to $60,8,>61$ to $80 ; 9,>81$ to $100 \%$ leaf area infected. From this, per cent disease intensity was computed. From the mean per cent disease intensity (PDI), per cent disease control (PDC) was calucated using formula given by Wheeler (1969) as below. Plants sprayed with water served as control.

\section{Calculation and statistical analysis}

Disease intensity was calculated after spray. Per cent disease control was calculated by following formula:

Disease control $(\%)=$

$$
\frac{\text { PDI in control - PDI in treatment }}{\text { PDI in control }} \times 100
$$

The data of per cent disease intensity in all the experiments were transformed to their Arcsin values (Fisher 

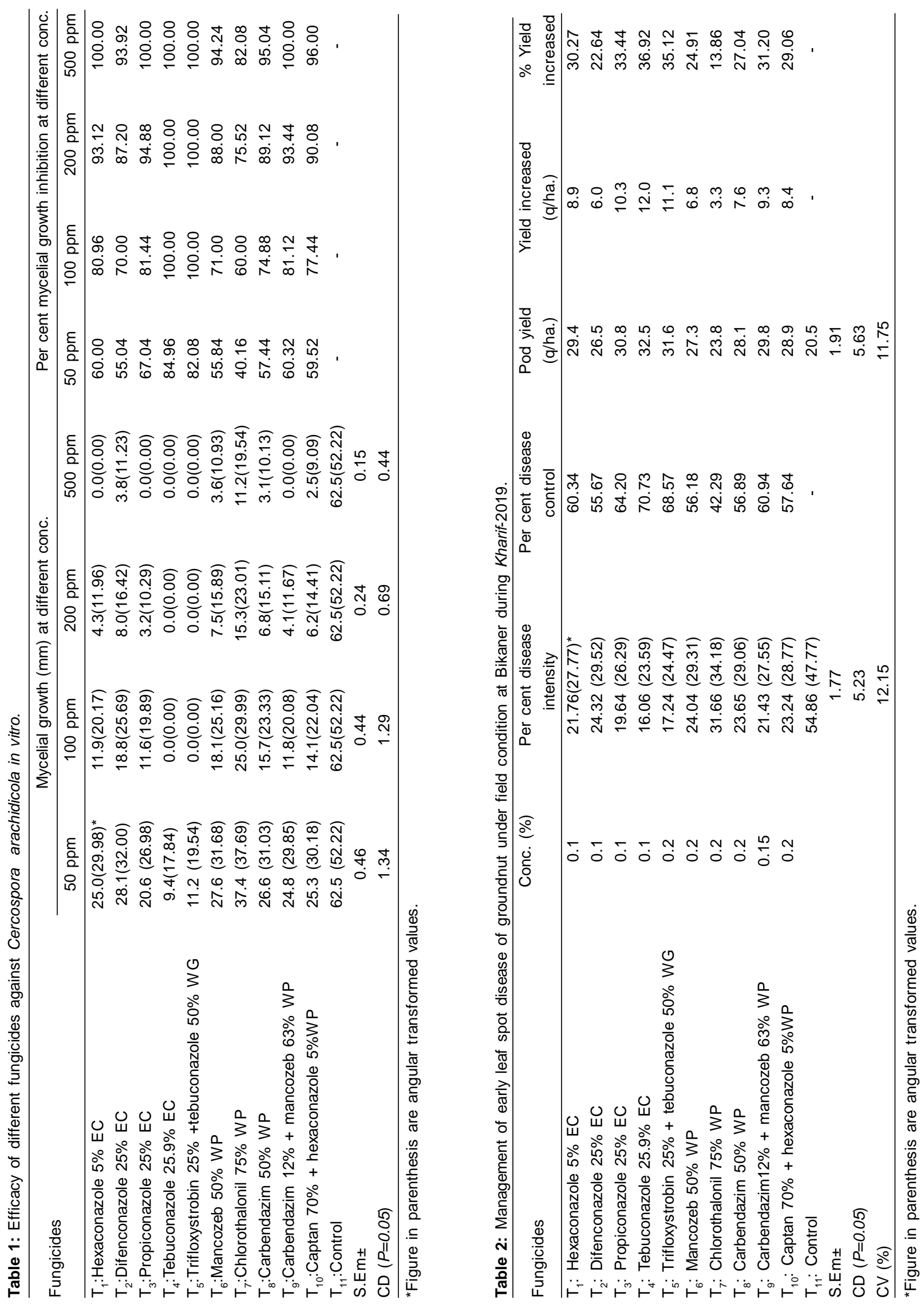
and Yates, 1963). The statistical analysis of the data of all the laboratory experiments were done following Completely Randomized Design. The data of field experiment was analyzed following Randomized Block Design (Cochran and Cox, 1957). Economics of each treatment was also computed.

\section{RESULTS AND DISCUSSION Efficacy of fungicides against mycelial growth}

The efficacy of ten (systemic, contact and combi) fungicides were tested at 50, 100, 200 and 500 ppm concentrations by poison food technique on mycelial growth of Cercospora arachidicola under in vitro. The data presented in Table 1 and Plate 1 showed that all the ten fungicides caused significantly reduction in mycelial growth as compared to control. Tebuconazole $25.9 \%$ EC was found most effective followed by trifloxystrobin $25 \%$ + tebuconazole $50 \%$ WG and propiconazole $25 \%$ EC resulting in significantly reduction of mycelial growth of $C$. arachidicola. At $50 \mathrm{ppm}$ concentration, maximum per cent growth inhibition of $C$. arachidicola was observed in tebuconazole $25.9 \%$ EC $(84.96 \%)$ followed by trifloxystrobin $25 \%$ + tebuconazole $50 \%$ WG (82.08\%) and propiconazole 25\% EC (67.04\%). At 100 ppm concentration, cent per cent growth inhibition of $C$. arachidicola was observed in tebuconazole $25.9 \%$ EC and trifloxystrobin 25\% + tebuconazole 50\% WG. Propiconazole 25\% EC gave (81.44\%) mycelial growth inhibition at $100 \mathrm{ppm}$ followed by carbendazim 12\%+ mancozeb 63\% WP (81.12\%) and hexaconazole 5\% EC $(80.96 \%)$. Minimum mycelial growth inhibition was observed in chlorothalonil $75 \%$ WP $(60 \%)$ followed by difenconazole $25 \%$ EC (70\%) and mancozeb 50\% WP (71\%). At 200 and 500 ppm concentrations, cent per cent growth inhibition of C. arachidicola was also observed in tebuconazole $25.9 \%$ EC and trifloxystrobin 25\% + tebuconazole 50\% WG. Propiconazole $25 \%$ EC gave also cent per cent mycelial growth inhibition at 500 ppm.

Earlier workers Nath et al., (2013) evaluated different fungicides viz.,tebuconazole $(0.05 \%, 0.10 \%, 0.15 \%, 0.20 \%$ and $0.40 \%)$, folicur $(0.10 \%)$ and mancozeb $(0.30 \%)$ in vitro against late leaf spot of groundnut caused by Phaeoisariopsis personata and maximum per cent growth inhibition of pathogen was reported in tebuconazole $0.40 \%$ (87.97\%) followed by tebuconazole $0.2 \%(85.24 \%)$ and tebuconazole $0.15 \%(83.50 \%)$. Among these, tebuconazole $0.15 \%$ was found to be optimum. In leaf spot of husk tomato caused by Cercospora sp. where in 100 per cent inhibition of conidial germination of the pathogen was noticed at 30 ppm of tebucnozole (Ruben et al., 2007). Mushrif et al., (2017b) observed that fungicides tebuconazole at $50 \mathrm{ppm}$ and fungicide carbendazim at $100 \mathrm{ppm}$ could suppress the germination of the spores of Cercospora arachidicola and Cercosporidium personatum completely under in vitro conditions. In the present studies, the fungicide tebuconazole and trifloxystrobin $25 \%+$ tebuconazole were

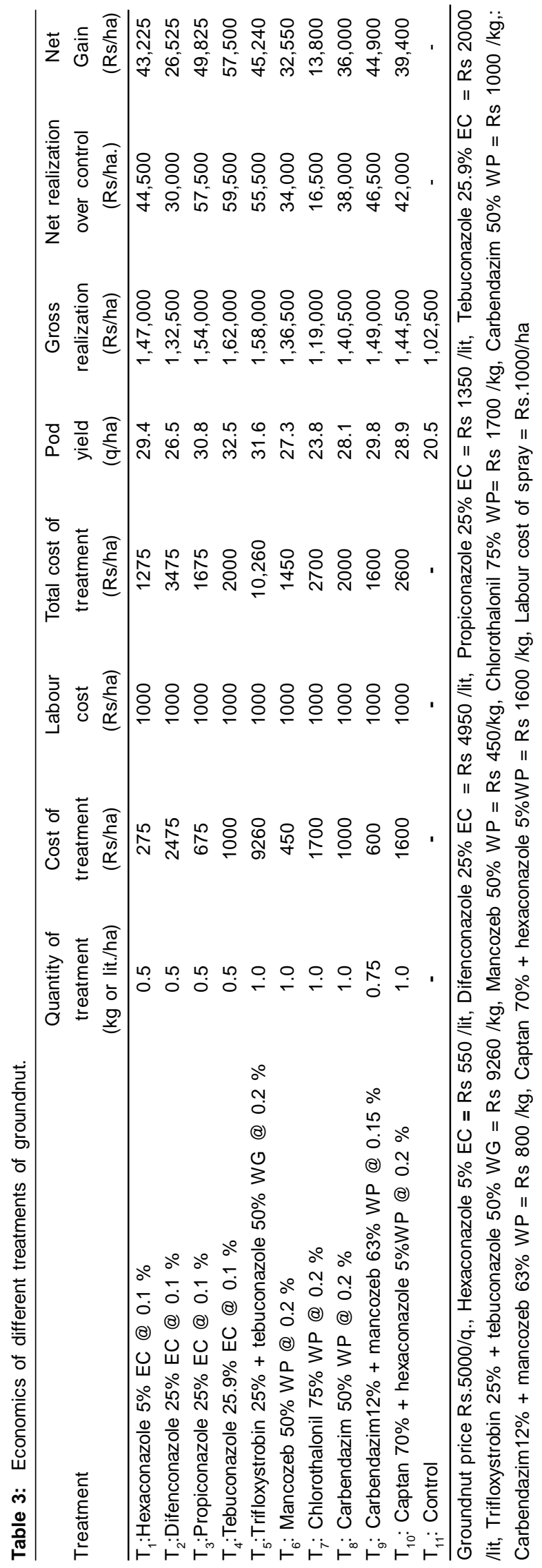

Legume Research- An International Journal 


\section{Fungicides \\ Hexaconazole $5 \%$ EC \\ Difenconazole $25 \%$ EC \\ Propiconazole $25 \%$ EC \\ Tebuconazole $25.9 \%$ EC}

Trifloxystrobin $25 \%+$ tebuconazole $50 \%$ WG

Mancozeb $50 \%$ WP

\section{Chlorothalonil $75 \%$ WP}

\section{Carbendazim $50 \%$ WP}

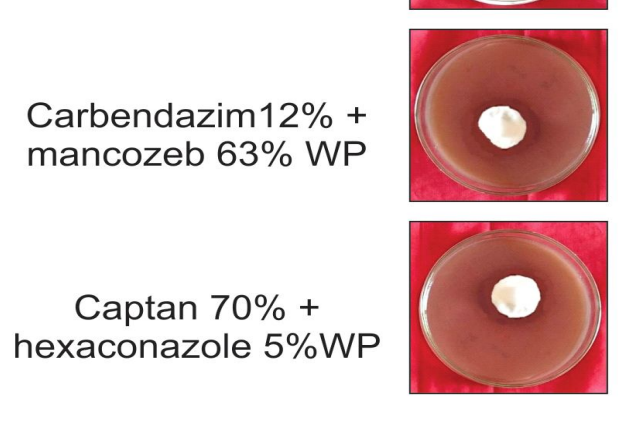

Control
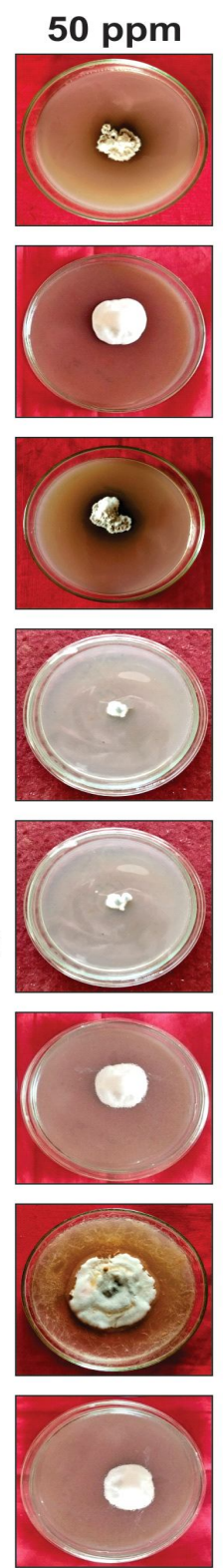
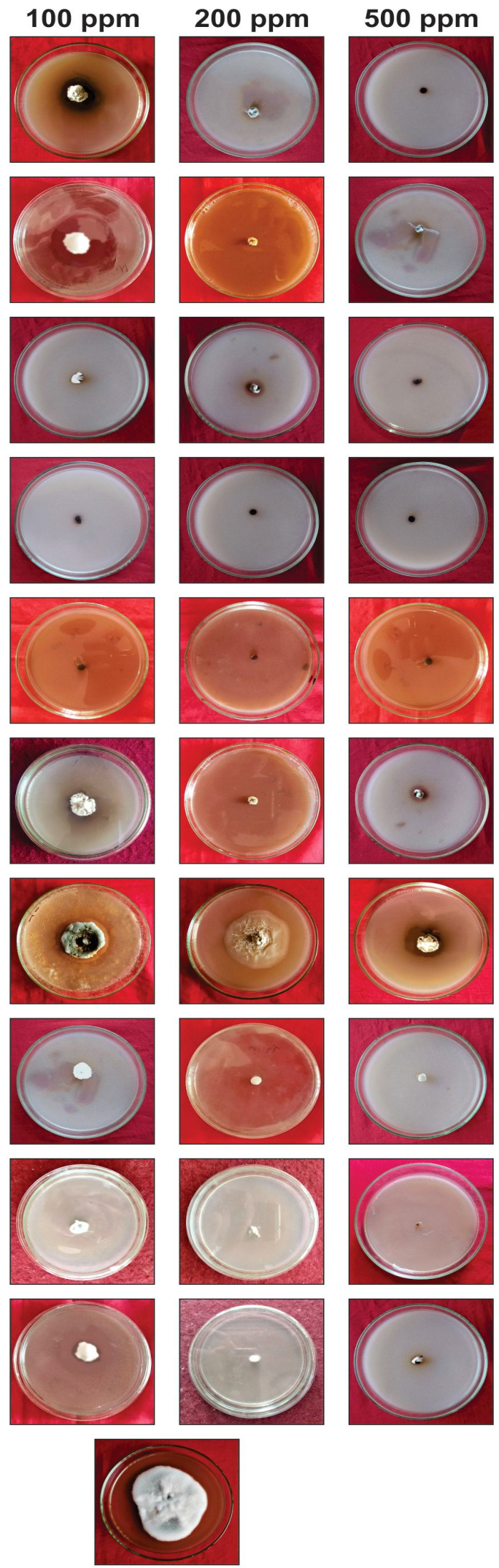

Plate 1: Efficacy of different fungicides against $C$. arachidicola in vitro. 
effective in inhibiting the mycelial growth of $C$. arachidicola in vitro. These studies are also in confirmatory to our results.

\section{Field efficacy of different fungicides against early leaf} spot disease

Ten fungicides (systemic, contact and combi products) viz., hexaconazole $5 \%$ EC $(0.1 \%)$, difenconazole $25 \%$ EC $(0.1 \%)$, propiconazole $25 \%$ EC $(0.1 \%)$, tebuconazole $25.9 \%$ EC (0.1\%), trifloxystrobin $25 \%$ + tebuconazole $50 \%$ WG $(0.2 \%)$, mancozeb $75 \%$ WP $(0.2 \%)$, chlorothalonil $75 \%$ WP $(0.2 \%)$, carbendazim $50 \%$ WP $(0.2 \%)$, carbendazim $12 \%+$ mancozeb $63 \%$ WP $(0.15 \%)$ and captan $70 \%+$ hexaconazole $5 \%$ WP $(0.2 \%)$ were tested as a foliar application to assess their efficacy against early leaf spot disease of groundnut under field condition during Kharif 2019. The application of fungicide caused significant reduction in intensity of early leaf spot in groundnut (Table 2). However, amongst the different fungicides tested, application of single spray of tebuconazole $25.9 \%$ EC @ $0.1 \%$ concentration (treatment $\mathrm{T}_{4}$ ) found most effective in controlling early leaf spot disease and had $16.06 \%$ disease intensity during Kharif- 2019. This treatment caused 70.73 per cent reduction in leaf spot intensity as compared to untreated control plots. Treatment $\mathrm{T}_{5}$, i.e. single spray of trifloxystrobin $25 \%$ + tebuconazole $50 \%$ WG @ $0.2 \%$ found next best option where it was at par with treatment $\mathrm{T}_{4}$. It has reduced 68.57 per cent leaf intensity as compare to untreated control plots. It was followed by propiconazole $25 \%$ EC $(64.20 \%)$. Among the tested fungicides, minimum disease control (42.29\%) was recorded by chlorothalonil $75 \%$ WP at $0.2 \%$ concentration (treatment $\mathrm{T}_{7}$ ). The maximum disease intensity of $54.86 \%$ was recorded in control plot $\left(T_{11}\right)$.

\section{Pod yield}

The fungicides treatments had significant effects on pod yield (Table 2) and all the treatments were found effective in enhancing pod yield as compared to contol. The highest pod yield $32.5 \mathrm{q} / \mathrm{ha}$ was recorded in the treatment $\mathrm{T}_{4}$ i.e., foliar spray of tebuconazole 25.9\% EC @ 0.1\% concentration. It was followed by trifloxystrobin $25 \%+$ tebuconazole 50\% WG @ $0.2 \%$ concentration (31.6 q/ha) and treatment $\mathrm{T}_{3}$ i.e. propiconazole 25\% EC @ $0.1 \%$ concentration ( $30.8 \mathrm{q} / \mathrm{ha}$ ). Treatment $\mathrm{T}_{4}$ had $12.0 \mathrm{q} /$ ha greater pod yield than control followed by Treatment $T_{5}(11.1 \mathrm{q} / \mathrm{ha})$. Treatment $T_{4}$ and $T_{5}$ increased 36.92 per cent and 35.12 per cent pod yield as compare to control plots, respectively. The minimum pod yield was observed in treatment $\mathrm{T}_{7}$ i.e. one spray of chlorothalonil 75\% WP @ $0.2 \%$ (23.8 q /ha). In control plot where $20.5 \mathrm{q} \mathrm{ha}^{-1}$ pod yield was obtained.

The economics computed on various treatments (Table3) revealed that highest net gain Rs 57,500/ha was obtained in the treatment $\mathrm{T}_{4}$, i.e. foliar spray of tebuconazole $25.9 \%$ EC @ $0.1 \%$ concentration followed by $\mathrm{T}_{3}$, i.e. foliar spray of propiconazole 25\% EC @ $0.1 \%$ concentration (Rs. 49,825/ ha). Similarly, Mushrif et al., (2017b) observed that the tebuconazole $(0.1 \%)$ was effective in registering least disease severity in terms of percent disease intensity, 13.67 and 15.07 and highest pod yield, 2295.92 and $2551.02 \mathrm{~kg}$ $\mathrm{ha}^{-1}$ and haulm yield,2716.84 and $3066.22 \mathrm{~kg}$ ha ${ }^{1}$, respectively for two different seasons. Their experimental finding is similar to present finding. The findings of the present research work was in consonance with the findings of Mushrif et al., (2017b) where they had evaluated seven fungicides comprising of triazoles (difenoconazole, propiconazole, tebuconazoleand bitertanol), dithiocarbamate (mancozeb), benzimidazole (carbendazim) and phthalimide (chlorothalonil) in the field against Cercospora arachidicola and Cercosporidium personatum, the causal agents of tikka disease of groundnut during the kharif 2008 and 2009. They have reported that the tebuconazole $(0.1 \%)$ was effective in registering least percent disease intensity, 13.67 and 15.07 with maximum pod yield, 2295.92 and $2551.02 \mathrm{~kg}$ ha${ }^{1}$ and haulm yield, 2716.84 and $3066.22 \mathrm{~kg} \mathrm{ha}^{-1}$, respectively for two different seasons. Similarly Khan et al. (2014) evaluated the efficacy of different fungicides on cercospora leaf spot of groundnut and maximum disease control with high pod yield was observed with nativo and triazole fungicides. Nath et al. (2013) studied the efficacy of tebuconazole against late leaf spot disease of groundnut and observed that tebuconazole $(0.15 \%)$ gave best result and reduced the disease intensity to $52.42 \%$ and increased pod yield up to $67 \%$. These findings also corroborated to our investigation.

\section{CONCLUSION}

It can be concluded unequivocally considering the results that in groundnut cv HNG-69, application of single foliar spray of tebuconazole $25.9 \%$ EC @ $0.1 \%$ concentration was an effective treatment which reduced early leaf spot intensity and increased pod yield with maximum net return under field conditions followed by foliar spray of trifloxystrobin 25\% + tebuconazole 50\%WG @ $0.2 \%$ concentration. These fungicides are better option of groundnut cultivators for enhancing the pod yield by managing early leaf spot disease.

\section{ACKNOWLEDGEMENT}

The authors are very much thankful to Dr P.S. Shekhawat, Zonal Director Research, Agricultural Research Station, Swami Keshwanand Rajasthan Agricultural University, Bikaner for providing groundnut seeds and land to conduct the experiment.

\section{REFERENCES}

Anonymous (2019). Indian oilseeds and produce export promotion council kharif-2019 survey of groundnut crop (Under ministry of commerce, Gol).

Basu, M.S. and Singh, N.B. (2004). Groundnut research in India. National Centre for groundnut (ICAR) Junagadh, Gujarat, pp. 488. 
Cochran, W.G. and Cox, G.M. (1957). Statistical analysis when residual effects are present. Experimental Designs. $2^{\text {nd }}$ ed. John Wiley and Sons, Inc.New York, pp. 135.

Damicone, J.P., Duthie, J.A. and Melouk, H.A. (1999). Effects of temperature and wetness duration on infection of peanut cultivars by Cercospora arachidicola. Phytopathology. 89(8): 653-659.

Fisher, R.A. and Yates, F. (1963). Statistical tables for biological, agricultural and medical research. Oliver and Boyd, Edinburgh, London, pp. 146.

Ghuge, S.S., Mayee, C.D. and Godbole, G.M. (1981). Assessment of losses in peanut due to rust and tikka leaf spots. Indian Phytopathology. 34: 179-182.

Khan, A.R., ljaz, M., Haq, I.U., Farzand, A. and Tariqjaved, M. (2014). Management of cercospora leaf spot of groundnut (Cercospora arachidicola and Cercosporidium personatum) through the use of systemic fungicides. Cer. Agro. Mol. 47(2): 97102.

Mohammed, Z.H. (2004). Evaluation of groundnut varieties for resistance to cercospora leaf spot diseases in the Sudan savanna of Nigeria. M.Sc. Thesis, Department of Crop Protection, University of Maiduguri, Nigeria. pp. 77

Mushrif, S.K., Manju, M.J., Shankarappa, T.H. and Nagaraju, H.T. (2017b). Comparative efficacy of fungicides against tikka disease of groundnut caused by Cercospora arachidicola and Cercosporidium personatum. The Ecology. 11(1 and 2): 67-71.

Nath, B.C., Singh, J.P., Srivastava, S. and Singh, R.B. (2013). Management of late leaf spot of groundnut by different fungicides and their impact on yield. Plant Pathology Journal. 12: 85-91.
Nene, Y.L. and Thapliyal, P.N. (1973). Fungicide in plant diseases control. (Third Edition; Oxford and IBH publishing Co. Pvt. Ltd., New Delhi. pp. 325.

Oke, O.L. (1967). Chemical studies on some Nigerian pulses. W. Af. J. Bio. Appl. Chem., 9:52-55.

Ruben, F.G., Jeovan, A.A.D., Beatriz O.V.C., Jose A.T.S. and Rosa, M.L.E. (2007). Identification and chemical control of the causal agents of leaf spot and powdery mildew of husk Mexico. Revista Mexicana de-Fitopatologia. 25: 1-10.

Savage, G.P. and Keenan, J.I. (1994). The composition and nutritive value of groundnut kernels. In The groundnut crop (Springer, Dordrecht), pp. 173-213.

Subrahmanyam, P., Mehan, V.K., Nevill, D.J. and McDonald, D. (1980). Research on fungal diseases of groundnut at ICRISAT, pp. 6.

Subrahmanyam, P., McDonald, D., Gibbons, R.W., Nigam, J.N. and Nevill, D.J. (1982). Resistance to rust and leaf spot disease in some genotypes of Arachis hypogaea. Peanut Science. 9: 6-10.

Vincent, J.M. (1947). The esters of four-hydroxybenzoic acid and related compounds. Part I. Methods for the study of their fungistatic properties. Journal Social Chemical Industry. 66: 149-155.

Waliyar, F., Adamou, M.and Traore, A. (2000). Rational use of fungicide applications to maximize peanut yield under foliar disease pressure in West Africa. Plant Disease. 84(11): 1203-1211.

Wheeler, B.E.J. (1969). An Introduction to Plant Disease, John Willeyand Sons Ltd., London, pp. 301. 